\title{
O ARTÍSTICO NO COTIDIANO: OS SIGNIFICADOS DA ARTE DE FRIDA KAHLO NOS CALÇADOS DA AREZZO
}

\author{
THE ARTISTIC IN THE QUOTIDIAN: THE MEANINGS OF FRIDA \\ KAHLO'S ART IN THE AREZZO FOOTWEAR
}

\author{
EL ARTÍSTICO EN EL COTIDIANO: LOS SIGNIFICADOS DEL \\ ARTE DE FRIDA KAHLO EN EL CALZADO DE AREZZO
}

\author{
Maria EdUARda CARRENHo FABrin ${ }^{\mathrm{I}}$ \\ Jỗo Paulo Baliscei ${ }^{I I}$ \\ ViníCIUS STEIN ${ }^{\mathrm{III}}$
}

Resumo Ainda hoje, a vida e obra de Frida Kahlo, artista mexicana cuja estética é amplamente reconhecida, continuam repercutindo em imagens cinematográficas, bibliográficas e publicitárias. Neste artigo, nosso objetivo é identificar e analisar as maneiras como as referências artísticas são veiculadas e consumidas nas visualidades contemporâneas. Para isso, investigamos duas produções distintas denominadas Viva la Vida. A primeira trata-se de uma pintura do gênero natureza-morta, elaborada por Frida Kahlo em 1954, pouco antes de sua morte. A segunda constitui-se de uma coleção de bolsas e calçados produzida e divulgada pela marca Arezzo ao longo de 2015. Quais as convergências expressivas apresentadas entre esses dois artefatos culturais? Quais os desdobramentos do artístico nas visualidades cotidianas? Respaldados no Estudo da Cultura Visual e nas referências oferecidas pelas duas versões de Viva la Vida, identificamos elementos de intersecção que aproximam a arte institucional às visualidades populares contemporâneas.

Palavras-chave: Arte; Frida Kahlo; Visualidades; Cultura Visual; Educação.

\footnotetext{
Universidade Estadual de Maringá (UEM), Maringá/PR - Brasil.

II Universidade Estadual de Maringá (UEM), Maringá/PR - Brasil.

III Universidade Estadual de Maringá (UEM), Maringá/PR - Brasil.
} 
Abstract Even today, the life and work of Frida Kahlo, a Mexican artist whose aesthetics is widely recognized, continues to be reflected in cinematographic, bibliographical and advertising images. In this article, our purpose is to identify and analyze the ways in which artistic references are conveyed and consumed in contemporary visuality. For this, we investigated two different productions called Viva la Vida. The first version of Viva la Vida is a painting of the still life genre, elaborated by Frida Kahlo in 1954, shortly before her death. The second version of Viva la Vida is a collection of handbags and shoes produced and disseminated by the Arezzo brand throughout 2015. What is the expressive convergences between these two cultural artifacts? What are the unfoldings of the artistic in quotidian visuality? Supported by the Study of Visual Culture and the references offered by the two versions of Viva la Vida, we identify elements of intersection that bring institutional art closer to contemporary popular visuals.

Key-words: Art; Frida Kahlo; Visuals; Visual Culture; Education.

Resumen Aún hoy, la vida y obra de Frida Kahlo, artista mexicana cuya estética es ampliamente reconocida, continúa reflejándose en imágenes cinematográficas, bibliográficas y publicitarias. En este artículo, nuestro propósito es identificar y analizar las maneras en que las referencias artísticas son transmitidas y consumidas en la visualidad contemporánea. Para esto, investigamos dos producciones diferentes llamadas Viva la Vida. La primera versión es una pintura del género de la bodegón, elaborada por Frida Kahlo en 1954, poco antes de su muerte. La segunda versión de Viva la Vida es una colección de bolsos y zapatos producidos y difundidos por la marca Arezzo a lo largo de 2015. ¿Cuáles son las expresivas convergencias entre estos dos artefactos culturales? ¿Cuáles son los despliegues de lo artístico en la visualidad cotidiana? Apoyados por el Estudio de la Cultura Visual y las referencias que ofrecen las dos versiones de Viva la Vida, identificamos elementos de intersección que acercan el arte institucional a las visuales populares contemporáneas.

Palabras clave: Arte; Frida Kahlo; Visuales; Cultura visual; Educación.

\section{INTRODUÇÃo}

Popularmente caracterizada como uma mulher forte e à frente de seu tempo, Magdalena Carmen Frieda Kahlo y Calderón (1907-1954), marcou o cenário de seu país e da época em que viveu, tanto por meio de suas produções artísticas, como pelo papel que desempenhou politicamente. Hoje, a estética característica do processo criativo da artista e a sua própria figura são alvos de idolatria e admiração por parte de diferentes pessoas. Apesar de Frida Kahlo ter morrido há mais de sessenta anos, sua vida foi e ainda é abordada por pesquisadores e pesquisadoras de diversas áreas (ARCQ, 2015; ARAS, 2000; PRADO, 2003; VASCONSELLOS, 2005; SOUSA, 2011; HAGHENBECK, 2011; LEVINZON, 2009; KETTENMANN, 2001; ALVES, 2015) e, para além da produção acadêmica e literária, tem sua vida e obra lembradas e valorizadas pelos mais variados segmentos artístico-comerciais. 
Para além da produção artística, o acidente, os relacionamentos, a sexualidade, a família e a saúde de Frida são temas abordados em filmes, livros, peças teatrais, músicas, páginas da web, inclusive, contemporâneas. O filme estadunidense Frida (2002), dirigido por Julie Taymor, o livro O Diário de Frida Kahlo: um autorretrato íntimo (1994) publicado pela José Olympio, a peça teatral escrita por Maria Adelaide do Amaral Frida e Diego (2015), a música Esquadro (1992) da compositora Adriana Calconhotto, que cita as cores de Frida, e também a página de um Coletivo Feminista veiculada a uma rede social chamada Não me Kahlo, são alguns exemplos que demonstram o quanto a obra e vida de Frida ainda provocam desdobramentos socioculturais. Em comum, esses artefatos usam diferentes linguagens e estratégias para aproximar as imagens e vivências de Frida aos sentimentos e desejos dos indivíduos contemporâneos. Nas salas de aula, por sua vez, as obras de Arte, as figuras dos/as artistas e os movimentos e períodos que caracterizam suas produções, se não significados em seu contexto e relacionados à contemporaneidade, como sugerem as Diretrizes Curriculares da Educação Básica - Arte (PARANÁ, 2008), podem parecer algo distante e indiferente aos alunos e alunas, mesmo quando dizem respeito a uma figura tão popular quanto Frida Kahlo.

Além desses artefatos exemplificados, há outros dois que se tornaram referências significativas para nós e, de formas distintas, atuam na produção e divulgação do conhecimento artístico sobre Frida Kahlo. O primeiro, uma pintura do gênero natureza-morta, elaborada pela própria Frida, em 1954, e o segundo, um produto oriundo da indústria de consumo, voltada à moda, e que carrega consigo referências da artista mexicana. Escolhemos tais artefatos para estruturar o corpus de análise deste artigo, pois, além de tematizarem a vida de Frida Kahlo, são marcados por um segundo ponto em comum: os dois trazem como título a expressão Viva la Vida.

Quais as convergências expressivas apresentadas entre esses dois artefatos culturais? Quais os desdobramentos do artístico nas visualidades cotidianas? Esses questionamentos atuam como provocações que nos auxiliam a delimitar o objetivo deste artigo que é identificar e analisar as maneiras como as referências artísticas são veiculadas e consumidas nas visualidades contemporâneas.

Para desempenhá-lo, desenvolvemos uma pesquisa bibliográfica e com delineamento analítico marcado pelo Estudo da Cultura Visual. Conforme Fernando Hernández (2007), o Estudo da Cultura Visual pode ser entendido como um campo de investigação pós-moderno que parte da discussão sobre as visualidades que preenchem o cotidiano contemporâneo, configurando-se como um fundamento para a elaboração de uma nova narrativa para a educação em Artes Visuais. Maria Emília Sardelich (2006) destaca que a Cultura Visual apresenta uma proposta ampla de leitura de imagens, já que contempla, para além dos significados estabelecidos, a produção ou a transformação que causam nas identidades. Para a autora:

A compreensão crítica aborda a cultura visual como um campo de estudo transdisciplinar multireferencial que pode tomar seus referentes da arte, da arquitetura, da história, da psicologia cultural, da psicanálise lacaniana, do construcionismo social, dos estudos culturais, da antropologia, dos estudos de gênero e 
mídia, sem fechar-se nessas ou somente sobre essas referências. Essa proposta ampla e aberta enfatiza que o campo de estudos não se organiza a partir de nomes de artefatos, fatos ou sujeitos, mas sim de seus significados culturais, vinculando-se à noção de mediação de representações, valores e identidades (SARDELICH, 2006, p. 466).

Em comum, Sardelich (2006) e Hernández (2007) tomam o Estudo da Cultura Visual como forma de subverter a objetividade e hegemonia na cultura erudita e também como campo de investigação que acolhe fragmentos que podem vir a significar o conhecimento já sistematizado. Como explica Jociele Lampert (2009, p. 37), as investigações feitas no bojo dos Estudos Culturais proporcionam "combinações entre Estudos Culturais, História da Arte, Antropologia Visual e Ciências Sociais, e assim [seguem] enfocando aspectos da cultura que se apóiem em imagens visuais".

Respaldados no Estudo da Cultura Visual e interessados em investigar essas duas versões de Viva la Vida, organizamos a estrutura deste artigo em dois momentos específicos. No primeiro deles, reunimos e relacionamos aspectos históricos e biográficos da artista mexicana Frida Kahlo, e elencamos um conjunto de obras a fim de especificar o gênero natureza-morta; e num segundo momento, analisamos as duas versões de Viva la Vida - a pintura e a coleção da marca Arezzo - considerando a proposta da Cultura Visual de significar o ensino de Arte a partir das visualidades cotidianas.

\section{O nascimento de Frida, a revolução e o muralismo}

Magdalena Carmen Frieda Kahlo y Calderón nasceu no dia 6 de julho de 1907, em um bairro mexicano chamado Coyoacán, contudo, segundo Lina Aras (2000), a artista insistia em afirmar ter nascido em 1910, ano do início da Revolução Mexicana, assinalando assim seu interesse e disposição nacionalista.

As produções de Frida foram realizadas dentro de um contexto de revolução social no México do século XX, em que diversas classes sociais se viam envolvidas em uma guerra civil a fim de reivindicar direitos e mudanças na organização do Estado. De acordo com Aras (2000), foi dentro desse cenário armado que Frida iniciou sua pintura marcada por seu nacionalismo e apreço pela sua origem e cultura.

Conforme Adonia Antunes Prado (2003, p. 144) a Revolução Mexicana ocorreu entre os anos 1910 e 1920, constituindo-se como um dos eventos mais marcantes da história do século XX, "tanto quanto a Revolução Russa". Para o autor, tal período expressou um momento de domínio dos/as fazendeiros/as, da elite em geral e também de submissão indígena, camponesa, operária e nacional, além de ter representado o apogeu de "contradições acumuladas ao longo de séculos de uma história de invasões e de recalcamento de povos e classes pelo domínio espanhol/católico, francês e estadunidense" (PRADO, 2003, p. 144).

As elites mexicanas, segundo Aras (2000), veem, em 1910, o surgimento da primeira revolução do século XX, que causou a morte de cerca de um milhão de mexicanos/as. Nesse momento, as populações mais pobres, tanto do campo quanto da cidade, que sofriam 
com a falta de "[...] alimentos agravada pela perda de colheitas de milho, aliaram-se às frações das classes possuidoras que se opunham ao governo central e derrubaram uma ditadura que durava várias décadas" (PRADO, 2003, p. 145).

Aras $(2000$, p. 2) aponta que a etapa da luta armada terminou apenas com a queda do Estado de Porfírio Díaz (1876-1910), e a elaboração de um novo Estado nacional que, embora trouxesse em sua estrutura a manutenção de propostas anteriores, constituiu-se mais como democrático do que o anterior, considerado autoritário. É nesse contexto de luta e revolução mexicana que o movimento Muralista ganha forças, demarcando-se em vários lugares, principalmente os públicos.

Desde a Antiguidade (4000 a.C.-476 d.C.), encontramos grandes painéis pintados em paredes de edifícios públicos, podendo ser caracterizados como pintura mural. Esse tipo de pintura focaliza comunicar ao povo valores específicos, sejam religiosos, políticos, artísticos ou uma mescla deles. O movimento Muralista no México está veementemente relacionado com a História da Arte local e com a Revolução Mexicana. De acordo com Camillo de Mello Vasconcellos (2005, p. 286), na época, o Muralismo foi criticado como sendo uma "[...] arte engajada, bíblia política dos pobres, panfleto em escala colossal, inovador ou pouco original, conservador ou moderno".

A pintura Mural mexicana teve início oficial na década 1920 e foi o principal estilo de arte moderna no país, com repercussão no continente americano e europeu. Concordamos com Vasconcellos (2005) que a Revolução Mexicana permitiu a emergência de tal corrente estética, embora ela já estivesse em estado de evolução anteriormente. O Muralismo caracterizou-se pelo esforço em criar uma imagem do povo que se via envolvido com a Revolução, tendo como principais artistas Diego Rivera (1886-1957), David Siqueiros (1896-1974) e Clemente Orozco (1883-1949).

Assim, mesmo que Frida Kahlo não tenha se destacado pelo envolvimento no Muralismo, entendemos que foi dentro desse contexto que ela teria se envolvido intrinsecamente com a arte de seu país, que desenvolvia uma personalidade própria conforme os costumes, hábitos, feitos heroicos e cultura local. ${ }^{1}$ Conforme Ana Maria Souza (2011, p. 32), a artista transcendeu o evento da revolução por meio de sua arte, ao refletir imagens de sofrimento e de humor, "[...] sua energia, além das piadas irônicas que ela própria fazia constantemente, mostram sua capacidade de sobrevivência, inclusive pictórica".

\section{Pincelando a história da arte: Vida e obra de Frida Kahlo}

Desde criança Frida mantinha um intenso contato com a técnica da pintura, pois, seu pai, que era fotógrafo, a levava para passear nos campos ensinando-a a pintar e a "usar a máquina fotográfica, a revelar, a retocar e a colorir as fotos" (ARAS, 2000, p. 4). Seu pai, Guillermo Kahlo (1871-1941), imigrante alemão descendente de judeus, casou-se com Matilde Gonzalez y Canderón (1874-1932), uma descendente espanhola e indígena com quem teve quatro filhas: Matilde, Adriana, Frida e Cristina (HAGHENBECK, 2011).

Até porque, como destaca Kettenmann (2001), a participação de mulheres no Muralismo não era comum e bem vista inclusive entre seus membros, predominantemente homens. 
Por vir de uma família de artesãos/ãs, segundo Haghenbeck (2011, p. 22), Guillermo herdou "[...] o olhar delicado para a vida, que o converteria num dos melhores fotógrafos de seu tempo". Para o autor, o pai de Frida aprendeu a arte de fotografar por meio de seu sogro e além de manusear produtos químicos de revelação, também envolveu-se fortemente com a técnica da pintura, dedicando-se aos gêneros de retrato e de paisagem, o que contribuiu para que Frida tivesse contato com a técnica desde cedo.

Gina Levinzon (2009) aponta que quando Frida nasceu, sua mãe, Matilde, católica devota, ainda vivenciava o luto pela perda de seu único filho homem que morrera logo após o parto. Isso acarretou uma série de sensações deprimentes tanto em Frida, que nasceu posteriormente à morte de seu irmão, quanto em sua mãe, que não pôde proporcionar vida a um esperado herdeiro-homem. Assim, tendo em vista que Matilde não tinha condições de alimentar sua própria filha por motivos de saúde e até mesmo por negação, Guillermo teve de contratar uma ama de leite indígena para amamentar e cuidar de Frida.

Aos 6 anos de idade, numa consulta em casa, Frida foi diagnosticada com poliomielite, doença que afetou os movimentos de sua perna esquerda (HAGHENBECK, 2011; LEVINZON, 2009). Como se não bastasse ter padecido com a doença que a fez temer a perda dos movimentos e da própria vida, aos 18 anos, Frida sofreu um acidente que comprometeu todo seu futuro e as ambições que depositava nele, como a de cursar Medicina. No dia 25 de setembro de 1925, quando voltava da Escola Nacional Preparatório onde ingressara em 1922, Frida seguia para casa em um ônibus, sentada próximo ao namorado, Alejandro, quando, de repente, o transporte público em que estavam colidiu com um trem, fazendo que Frida ficasse esmagada entre tubos e fosse atravessada por um corrimão. Isso fez Frida passar um longo período no hospital, permanecendo na cama, imobilizada por mais de três meses. Levinzon $(2009$, p. 51) aponta que foi por meio do desenho e da pintura que Frida tentou vencer o tédio, tendo sua cama " [...] coberta por um dossel onde foi fixado um espelho que permitia a Frida se ver e, desta maneira, tornar-se seu próprio modelo. Ela começou então a longa série de autorretratos".

No ano em que Frida ingressou na Escola Nacional Preparatória, o artista já reconhecido, Diego Rivera, estava trabalhando na encomenda de murais para as paredes do pátio da Secretaria de Educação Pública (SEP), do Ministério da Educação, onde foi encarregado de pintar 117 afrescos, terminando-os apenas quatro anos mais tarde (HAGHENBECK, 2011; LEVINZON, 2009; KETTENMANN, 2001). Em 1928, quando Rivera estava trabalhando na pintura de um mural intitulado Criação, Frida aparece procurando-o para que ele opinasse sobre suas primeiras pinturas.

Com isso, segundo Andréa Kettenmann (2001), depois de ter se envolvido em vários relacionamentos e uma separação, Diego Rivera casou-se com Frida Kahlo, 21 anos mais nova que ele, dando início a um percurso repleto de altos e baixos, marcado por anseios em comum, e por falhas desamorosas. Após casar-se com Diego em 1929, Frida começou a viajar por várias cidades da América do Norte, onde Rivera passou a receber encomendas frequentemente. Segundo Aras (2000), em sua trajetória, Frida morou em lugares como San Francisco, Detroit e Nova York, e essas viagens a fizeram investir em novas temáticas 
artísticas relacionadas com o estrangeiro, imprimindo, por exemplo, suas reflexões acerca da fronteira entre México e Estados Unidos. Por conta da fragilidade de sua saúde, Frida precisou ser hospitalizada inúmeras vezes para tratar de sequelas e outros problemas e, em 1932, em Detroit, um aborto espontâneo a levou novamente ao hospital, colocando fim ao anseio de ter um filho - o que refletiu posteriormente em algumas de suas obras.

Das 143 pinturas reconhecidas e atribuídas à artista, 55 delas são autorretratos, alguns com expressões de sofrimento e angústia, outros na companhia de animais e semblantes estáveis. Conforme Arcq (2015), Frida Kahlo é a artista mexicana de maior reconhecimento internacional, tendo um legado artístico constituído por narrativas autobiográficas em que explora seu corpo e sua sofrida realidade. Além de autorretratos (Figuras 1 e 2) e retratos, a artista também produziu obras que foram fortemente associadas ao movimento surrealista, embora Frida não se considerasse pertencente a tal movimento de vanguarda.

Figura 1 - Frida Kahlo. La coluna rota, 1944.

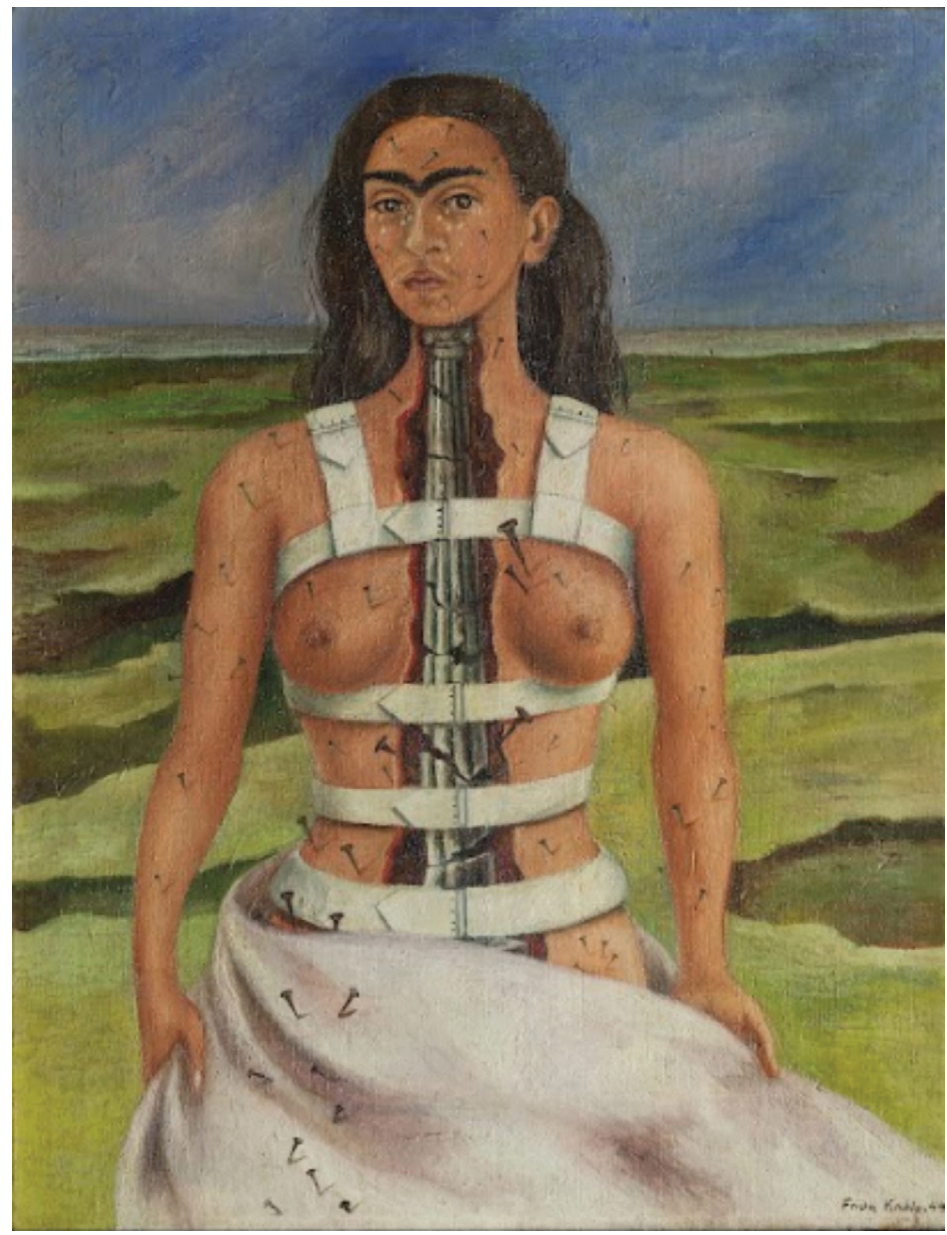

Fonte: Disponível em: $<$ http:// www.googleartproject.net $>$. Acesso em: 24 out. de 2016. 
Figura 2 - Frida Kahlo. Las dos Fridas, 1939.

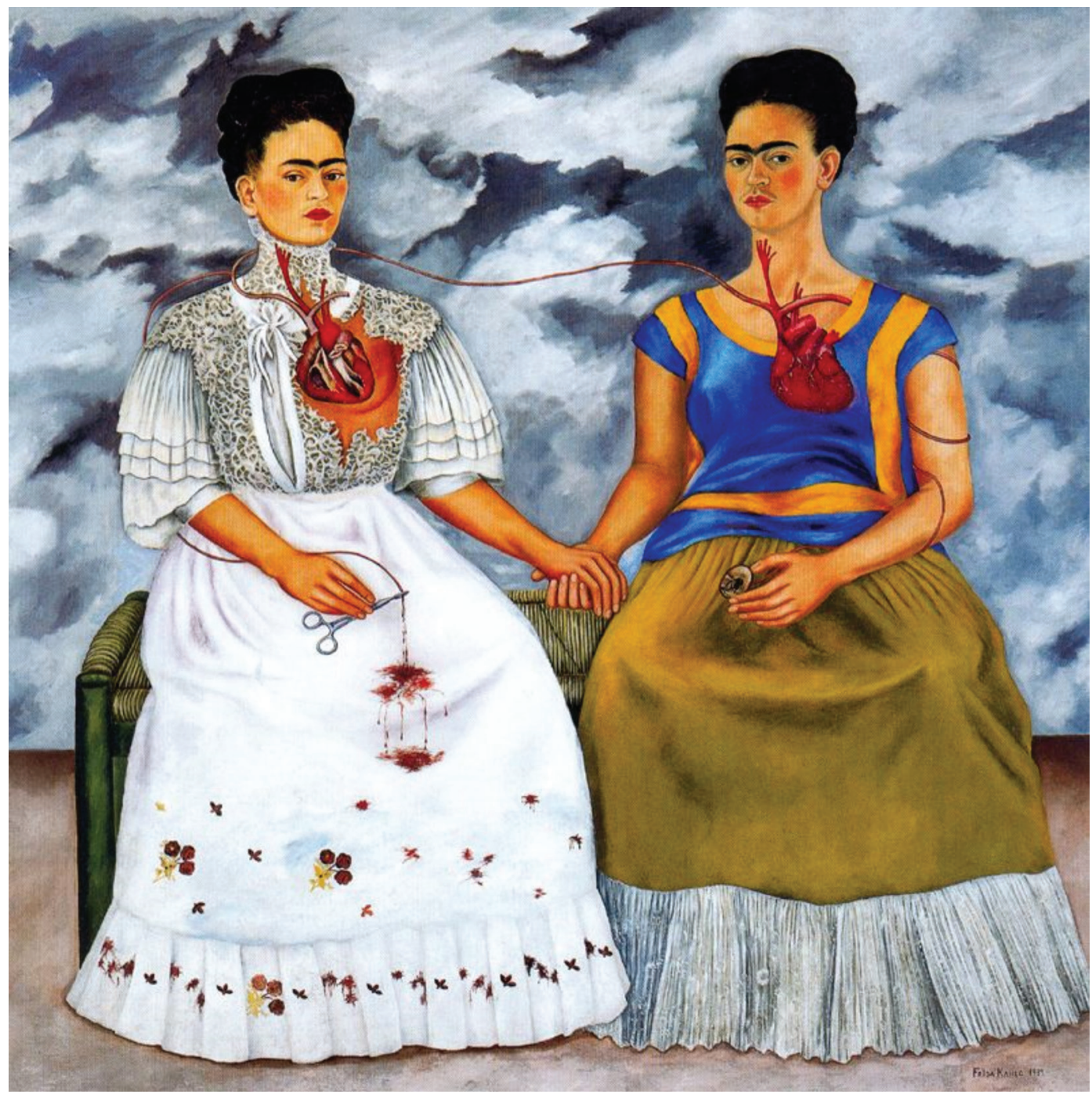

Fonte: Frida Kahlo - conexões entre mulheres surrealistas mexicanas, 2015, p. 32.

Cabe enfatizar que, além dos autorretratos, dos retratos e das composições associadas ao surrealismo, Frida também dedicou-se à produção de pinturas do gênero natureza-morta, dando ênfase, especificamente à fruta melancia, como pode ser percebido nas Figuras 3 e $4 .^{2}$

2 É interessante destacar que, assim como Frida, outras artistas mexicanas, como María Izquierdo (19021955) também se interessaram pela temática e gênero natureza-morta, o que pode ser percebido na obra Naturaleza Viva, 1946, que também retrata a fruta melancia. 
Figura 3 - Frida Kahlo. Los cocos, 1951.

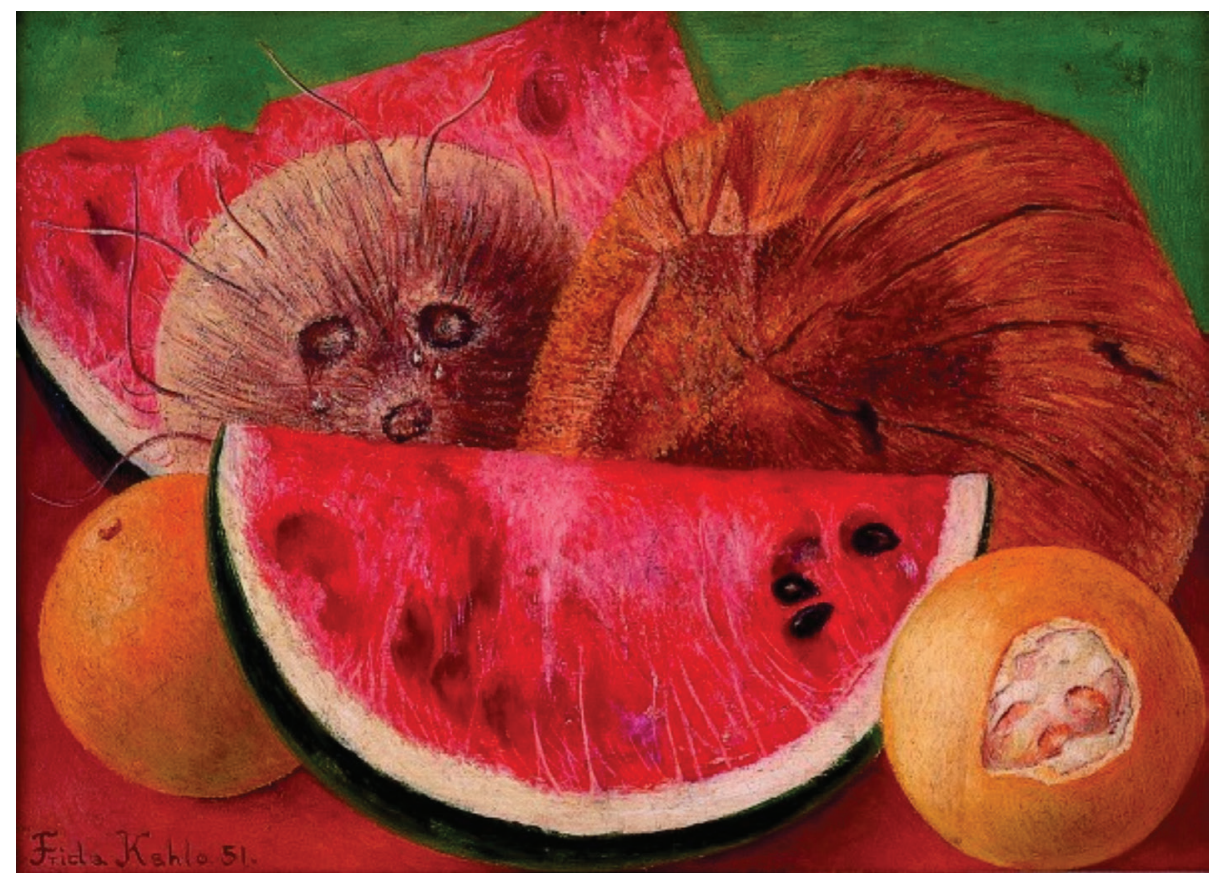

Fonte: Frida Kahlo - conexões entre mulheres surrealistas mexicanas, 2015, p. 96.

Figura 4 - Frida Kahlo. Naturaleza muerta cun loro y fruta, 1951.

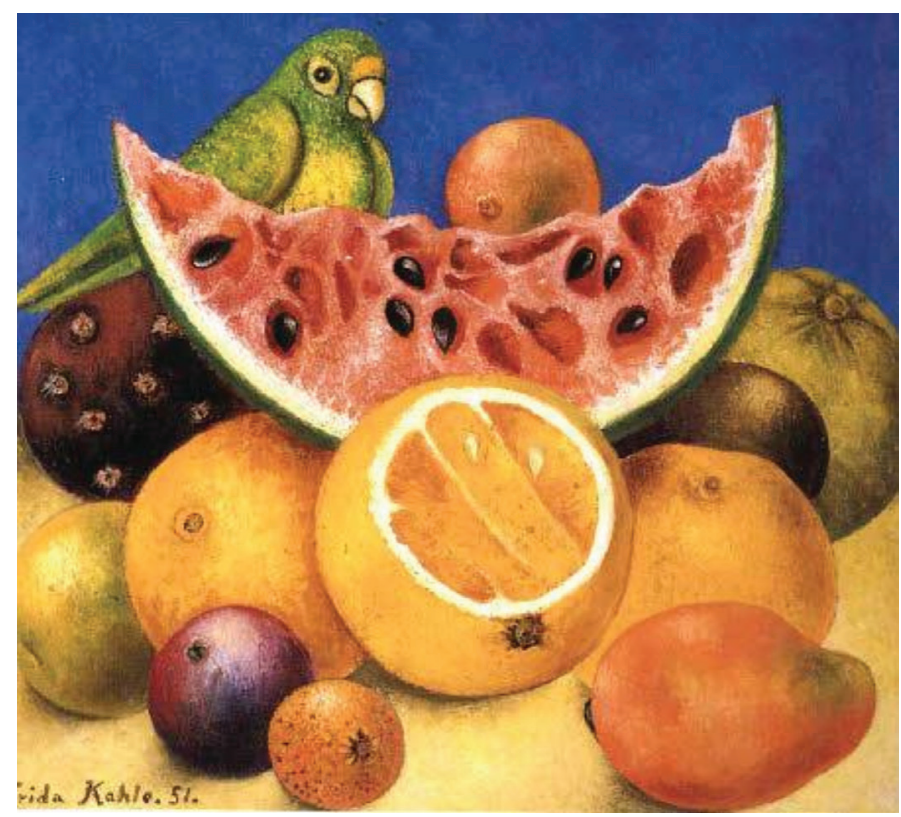

Fonte: <http://pinterest.com>. Acesso em: 10 nov. 2016. 
As pinturas que Frida fazia de natureza-morta são, na maioria das vezes, vivas, com tons vibrantes. Além disso, também há referência à iluminação refletida nas frutas ou outros alimentos tipicamente utilizados como oferenda no Dia dos Mortos, festejado no México no final de outubro e início de novembro. As festividades desses dias, conforme Maria Teresa Lemos (2009), envolvem a maior parte da população mexicana e consistem em rituais que unem a mestiçagem dos povos de todo o país, tratando-se de uma data em que se comemora a aproximação dos/as mortos/as e vivos/as. De acordo com Júlia Alves (2015), nesses dias de celebração, as pessoas se fantasiam de caveiras e de esqueletos e preparam e comem alimentos também nesses formatos. Segundo a autora, a festividade do Dia dos Mortos no México foi reconhecida como Patrimônio Oral e Intangível da Humanidade pela Organização das Nações Unidas para a Educação, a Ciência e a Cultura (UNESCO), no ano de 2003, por apresentar uma forma ímpar de cultuar os/as mortos/as, também pelo sincretismo entre o ritual ancestral indígena e católico.

De acordo com Arcq (2015, p. 92), as pinturas metafóricas em forma de naturezas-mortas, como aquelas elaboradas por Frida, configuraram uma estratégia “"...] para representar temas vedados como a sexualidade. Kahlo e [María] Izquierdo retomaram esse gênero tradicional e subverteram-no chamando as suas pinturas de "naturezas vivas"'. Algumas artistas utilizaram tal gênero para narrar histórias eróticas de amor ou abandono, usando as diversas frutas mexicanas com forte emprego simbólico. A pintura dos alimentos e dos rituais ligados à cozinha fascinavam tanto Kahlo quanto María Izquierdo, pintora mexicana, que tornavam as frutas motivos e inspiração para as suas telas que, de acordo com Arcq (2015, p. 40):

[...] parecem uma celebração de Eros onde as frutas sugerem os órgãos sexuais: suculentas melancias e carnosos mamões que se abrem mostrando as suas sementes, ou cachos de bananas pendurados. Segundo Frida "as frutas, assim como as flores nos falam com uma linguagem provocativa, nos ensinam coisas ocultas".

Assim, vemos que as frutas são temas recorrentes na pintura de Frida, e que a artista pinta uma natureza-morta que além de simbólica, é "viva" e análoga às suas reflexões sobre corpo e sexualidade. Percebemos que na maioria dessas pinturas há grande ligação entre a terra e a atmosfera celeste, o que diverge do cerne do gênero artístico, em que as frutas, tradicionalmente, são retratadas em ambientes internos, e pouco iluminados, como mesas e bancadas.

Assim, ainda sobre a trajetória de Frida, especificamente acerca de seus últimos anos de vida, Aras (2000) indica que os problemas de saúde da artista agravaram-se em 1946, quando foi submetida a uma cirurgia da coluna vertebral, em Nova York, sendo hospitalizada novamente, na cidade do México. Com isso, em 1950, ela é obrigada a permanecer "nove meses no hospital, após várias operações da coluna. Rivera, que se encontra numa fase muito produtiva da sua vida, aluga um quarto no hospital e passa aí quase todas as noites" (KETTENMANN, 2001, p. 77). Depois do acidente com o ônibus, Frida passou por 39 cirurgias para corrigir sua coluna e sua perna direita, que foi amputada abaixo do joelho em julho de 1953 (LEVINZON, 2009). Em 1954, foi novamente hospitalizada por dois meses, 
por conta de uma broncopneumonia, vindo a morrer, conforme Aras (2000), na madrugada do dia 13 de julho do mesmo ano, aos 47 anos de idade.

\section{Duas versões de ViVa La Vida: as cores de Frida e as cores da Arezzo}

Tendo apresentado aspectos da vida e da obra de Frida Kahlo, neste tópico, analisamos as duas obras intituladas Viva la Vida. Nomeamos o material de análise como "duas versões" por se tratar de dois grupos de artefatos compostos por elementos convergentes entre si, como as cores e especialmente os termos de seus títulos - Viva la Vida. A primeira versão de Viva la Vida é uma pintura a óleo sobre masonite, com dimensões de 52 x 72 $\mathrm{cm}$, que está localizada no Museu Frida Kahlo, como parte do acervo permanente da Casa Azul, onde residia a artista, no bairro Coyoacán, México. Composta quase que inteiramente por melancias, Viva la Vida de Frida Kahlo foi pintada em 1954, sendo a última pintura da artista que veio a falecer tempo depois de ter realizado tal produção.

Sete melancias integram a obra, sendo que há (des)pedaços e circunferências inteiras da fruta, como se as melancias ainda não tivessem sido abertas. Interpretamos que pelo seu frescor, suculência e vitalidade, a fruta pode remontar também à hidratação para o corpo, adubo para a terra e alegria para quem não esteja vivendo a vida (Figura 5).

Figura 5 - Frida Kahlo. Viva la Vida, 1954.

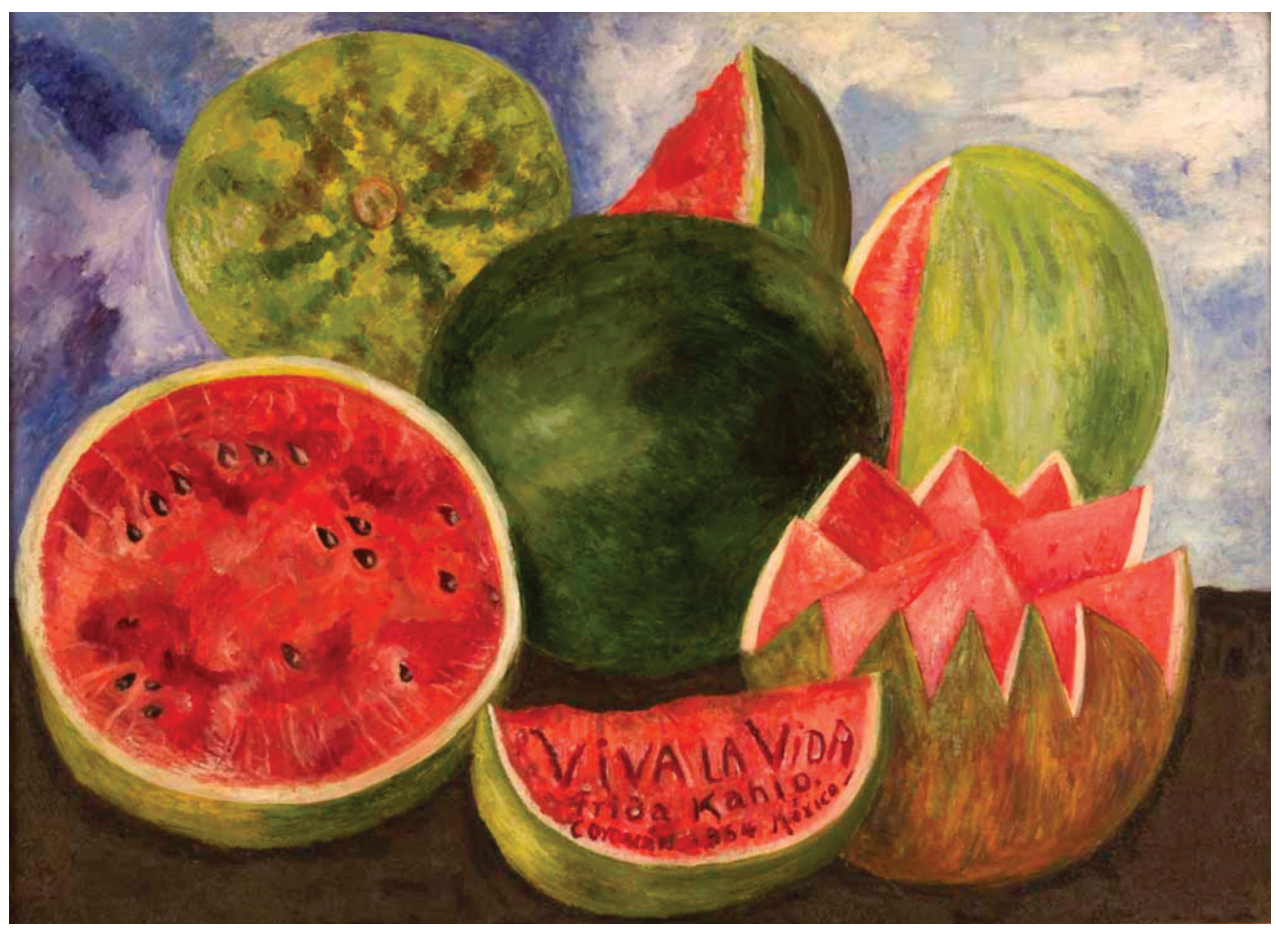

Fonte: Disponível em: <http://www.museofridakahlo.net>. Acesso em: 24 out. de 2016. 
A segunda versão de Viva la Vida diz respeito a uma coleção de bolsas e calçados voltada para o público feminino. Arezzo, a marca idealizadora dessa coleção, foi criada em 1972 pelos irmãos empreendedores Anderson e Jefferson Birman, sendo hoje "a maior marca de varejo de calçados femininos fashion da América Latina, reunindo conceito, alta qualidade e design contemporâneo", conforme informações disponíveis no site oficial. ${ }^{3}$ Em setembro de 2015, a marca desenvolveu a coleção cápsula ${ }^{4}$ inspirada na pintora mexicana, imprimindo, nos calçados e bolsas, as cores e flores tão suscitadas por Frida Kahlo. Composta por uma estampa floral e dez variações de cores - azul, rosa, amarelo, verde, vermelho, dourado, marrom, prata, branco e preto - essa linha de calçados e bolsas reflete o que comumente é tendência no verão, como estampas floral, cores quentes, e vibrantes, o que é típico da cultura mexicana (Figura 6).

Figura 6 - Artefatos que integram Viva la Vida (2015) na cor vermelha.
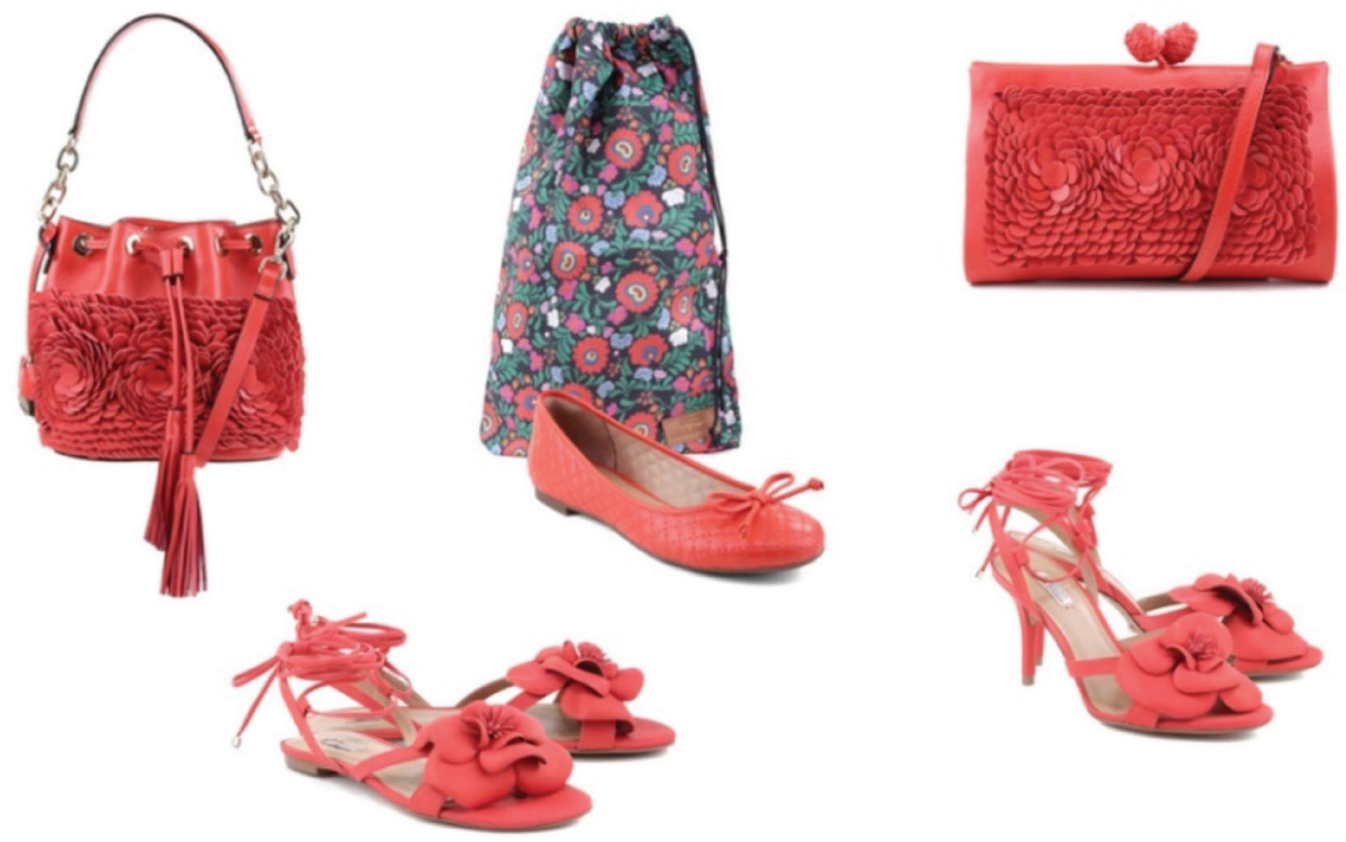

Fonte: Imagens da internet, 2016.

Tal coleção foi lançada pela marca, em 2015, concomitantemente à exposição Frida Kahlo - conexões entre mulheres surrealistas mexicanas (2015), ocorrida no Instituto Tomie Ohtake, em São Paulo, no período de 27 de setembro de 2015 a 10 de janeiro de $2016^{5}$ (ARCQ, 2015).

3 Disponível em: < https://www.arezzo.com.br/>. Acesso em: 18 out. 2016.

4 Uma coleção cápsula está relacionada a eventos especiais, além de ser menor e durar menos tempo que outras coleções.

5 Essa exposição apresentou a produção artística de um grupo de mulheres mexicanas e estrangeiras vinculadas ao surrealismo, tendo como figura central a artista Frida Kahlo. A mostra, organizada sob a curadoria da pesquisadora e Historiadora da Arte Teresa Arcq, reuniu cerca de 100 produções de 15 artistas (ARCQ, 2015). 
É interessante destacar que a marca Arezzo compôs o grupo de apoiadores da referida exposição - o que evidencia as convergências e sobreposições entre arte e consumo, uma vez que o investimento feito na exposição contribuiu para a divulgação e popularização da imagem da artista e, por conseguinte, para a sua identificação nos produtos lançados pela marca. Inclusive, como pode ser analisado na Figura 7, o evento de lançamento da coleção Viva la Vida, de Arezzo, aconteceu ao mesmo tempo e no mesmo espaço físico que a exposição Frida Kahlo - conexões entre mulheres surrealistas mexicanas (2015). O evento concentrou-se na área central do hall do Instituto Tomie Ohtake, e foi decorado com elementos característicos da cultura mexicana, como os cactos, os galhos secos, o chão árido com cascalhos, além das caveiras coloridas que junto da luz cênica compôs a ambientação.

Figura 7 - Evento de lançamento da coleção Viva La Vida no hall do Instituto Tomie Ohtake.

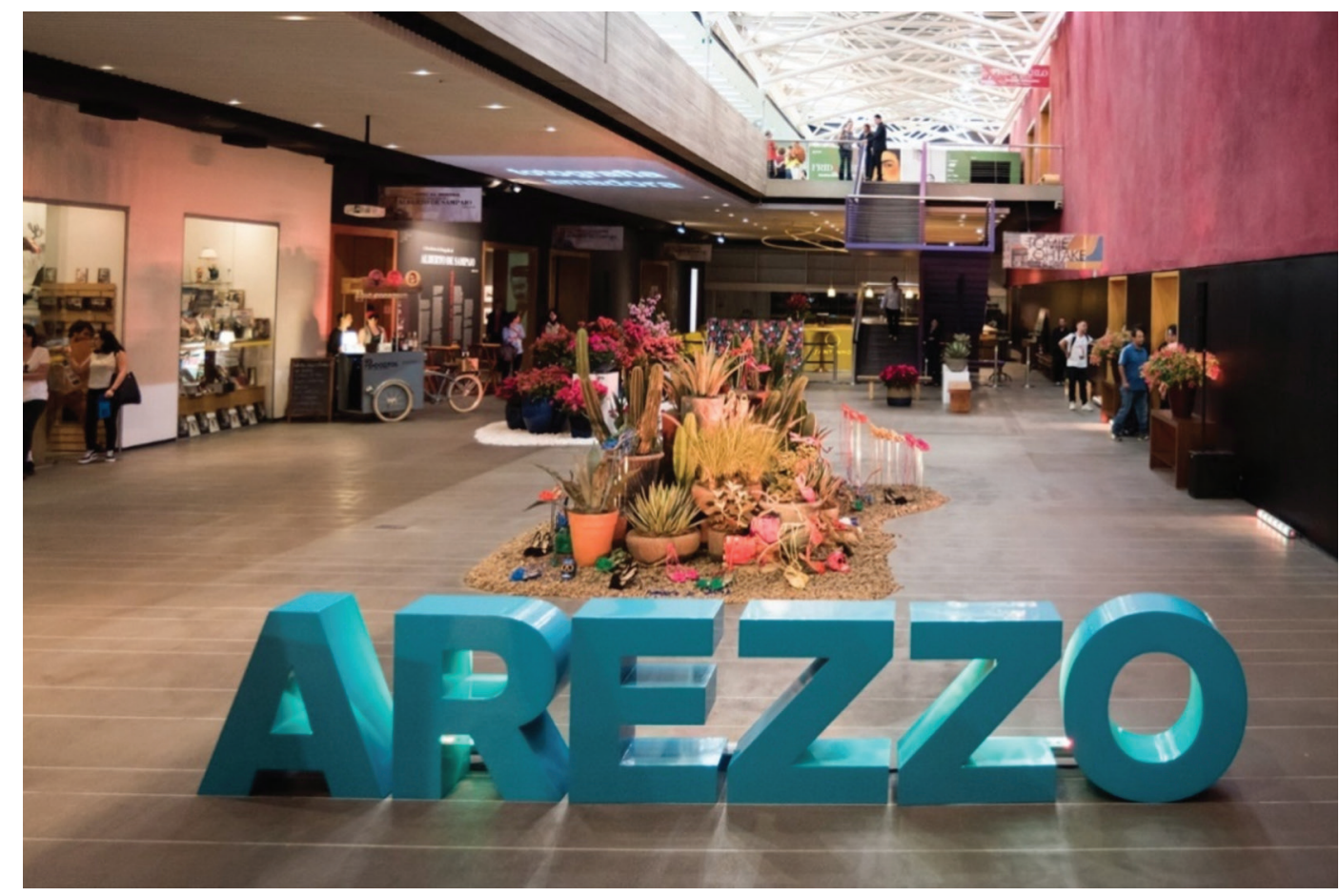

Fonte: Disponível em: <http://vogue.globo.com/lifestyle/festa/noticia/2015/09/viva-la-vida-arezzo-arma-festa-para-lancar-colecao-inspirada-em-frida-kahlo.html>. Acesso em: 19 out. 2016.

Como pode ser analisado, a decoração também foi integrada com as próprias sandálias da coleção Viva la Vida que, com suas flores, coloriram a atípica "vitrine". Em frente a essa ilha de elementos sugestivos que remontam fortemente à cultura mexicana e à estética abordada nos cenários pintados por Frida, há um grande letreiro com o nome da marca promotora da coleção e apoiadora da exposição Frida Kahlo - conexões entre mulheres surrealistas mexicanas (2015). Assim, vemos que como apoiadora oficial da exposição, 
a Arezzo dispôs de uma gama de visualidades para convidar o/a visitante a adentrar no mundo das pintoras envolvidas, especificamente no mundo de Frida, que é lembrada e mencionada no título da coleção.

Ainda, na Figura 7, podemos observar que atrás dessa "vitrine-ilha", há um painel com a identidade visual da exposição Frida Kahlo - conexões entre mulheres surrealistas mexicanas (2015), localizado no primeiro andar do prédio do Instituto Tomie Ohtake. Tal painel (Figura 8) está fixado em uma estrutura montada especificamente para a exposição, a fim de exibir vídeos que documentam a vida e obra da artista.

Figura 8 - Painel de entrada da exposição no Instituto Tomie Ohtake.

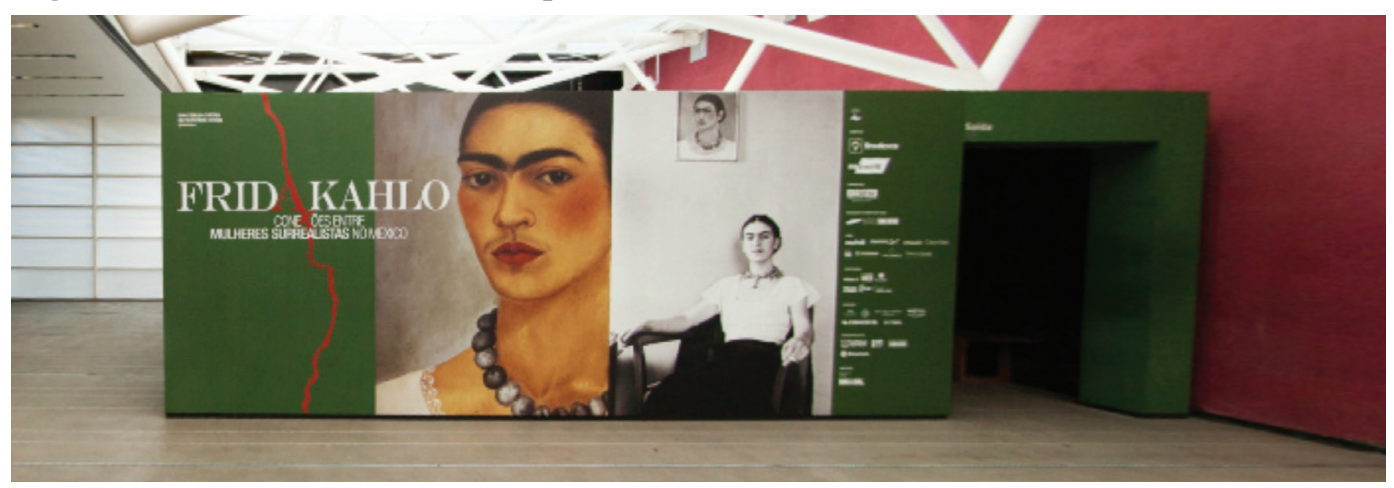

Fonte: Disponível em: <http://www.institutotomieohtake.org.br>. Acesso em: 4 nov. 2016.

Com isso, entendemos que o fato de a marca ter lançado Viva la Vida concomitantemente à mostra e, inclusive, no mesmo lugar em que ela foi realizada não sendo numa loja na cidade ou dentro de um shopping, faz que a figura e vida de Frida sejam consumidas culturalmente e para além dos olhos. Dizemos isso pois, além de observar, apreciar e analisar as produções da artista, agora, diante dos produtos da Arezzo, os/as visitantes podem vesti-la em seus corpos, pés, no dia a dia, colaborando para que sua arte seja suscitada em artefatos consumíveis e usáveis - ainda que os valores de tais calçados, sapatilhas, bolsas e carteiras não estejam ao alcance de todo e qualquer público.

Junto à identidade visual, a campanha publicitária dessa coleção incluiu imagens de bolsas, carteiras, sapatilhas, espadrilles, rasteiras e sapatos de salto, fotografados em superfícies e cenários tipicamente mexicanos, caracterizados pelas cores e folhagens que também evocam o clima tropical do país - concebendo à coleção ainda mais a especificidade das tendências primavera-verão. É possível observar na Figura 9 alguns desses elementos que fazem do México um país com características excêntricas e reconhecíveis popularmente, uma vez que a vegetação especialmente a de cactos, está relacionada com os desertos das fronteiras, bem como com o calor da região. 
Figura 9 - Ambientação do evento no hall do Instituto Tomie Ohtake.

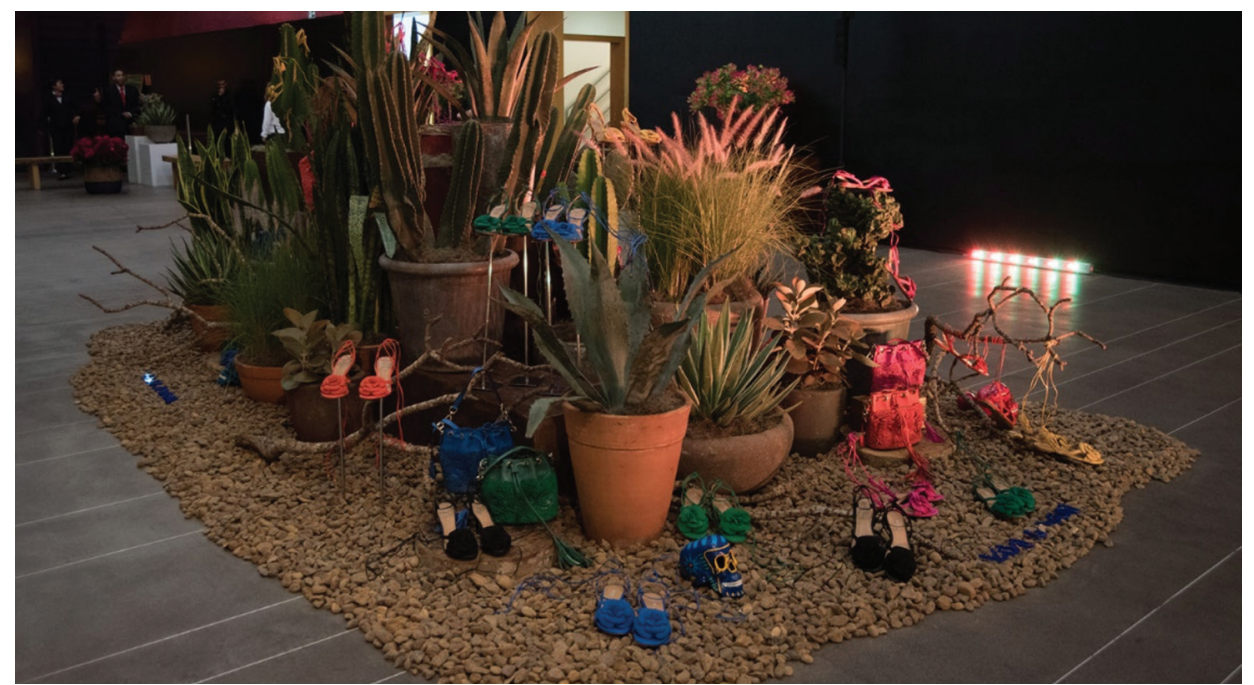

Fonte: Disponível em: <http://vogue.globo.com/lifestyle/festa/noticia/2015/09/viva-la-vida-arezzo-arma-festa-para-lancar-colecao-inspirada-em-frida-kahlo.html>. Acesso em: 19 out. 2016.

Quando a Arezzo recorre aos cactos para compor a ambientação e a "vitrine-ilha" que exibe e vende calçados e bolsas, apropria-se desse elemento, sabendo que o mesmo é representado em obras de Frida, como La Tierra (México), Diego, yo y el señor Xólotl, (1949), e que, inclusive, está presente na própria bandeira do México. Além dos cacFigura 10 - Registro fotográfico de Frida em sua cama segurando uma caveira.

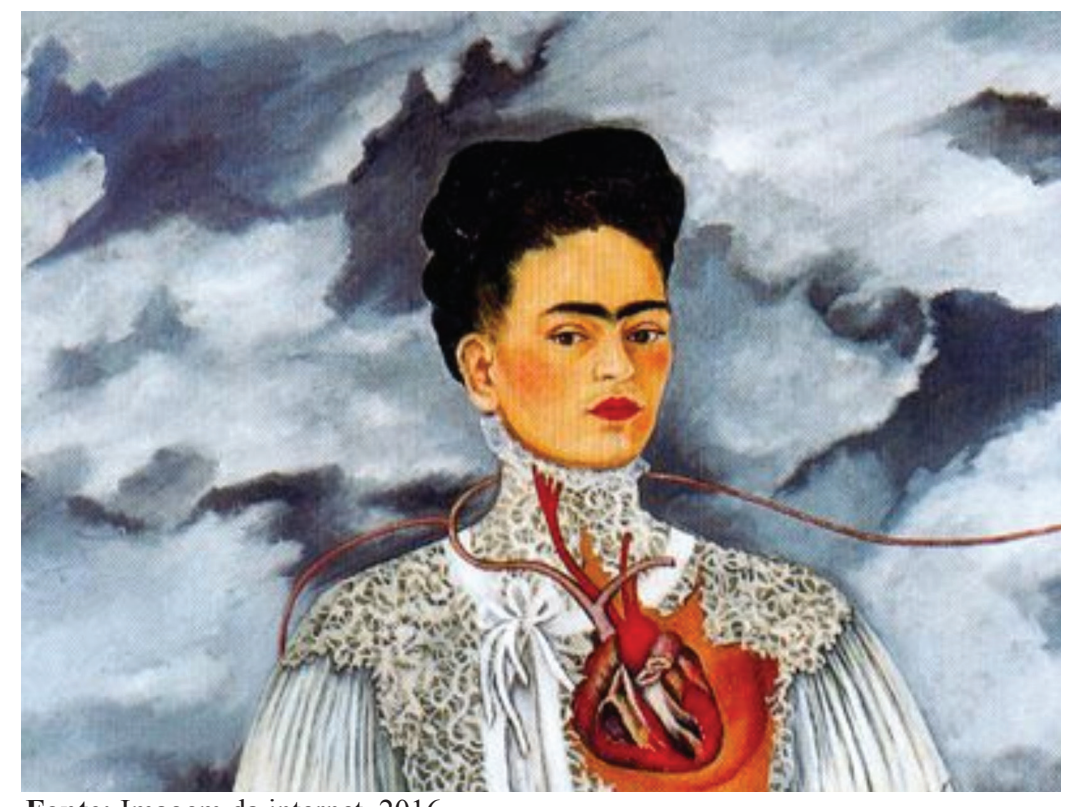

Fonte: Imagem da internet, 2016. tos e dos produtos da Arezzo, pequenas caveiras coloridas, localizadas no chão, compõem a ambientação da "vitrine-ilha". Na Figura 10, observamos um registro fotográfico em que Frida demonstra 
sua aproximação com o ícone da caveira, que é recorrente quando falamos em México e em Dia dos Mortos. Não obstante, tal ícone foi apropriado por Frida sendo, inclusive, representado por ela em algumas de suas obras, como Sem esperança (1945), (Figura 11), onde faz alusão à sua própria morte, que chamava carinhosamente de madrinha, chegando a tê-la como amiga imaginária, conforme Hagehnbeck (2011).

Figura 11 - Frida Kahlo. Sem esperança, 1945.

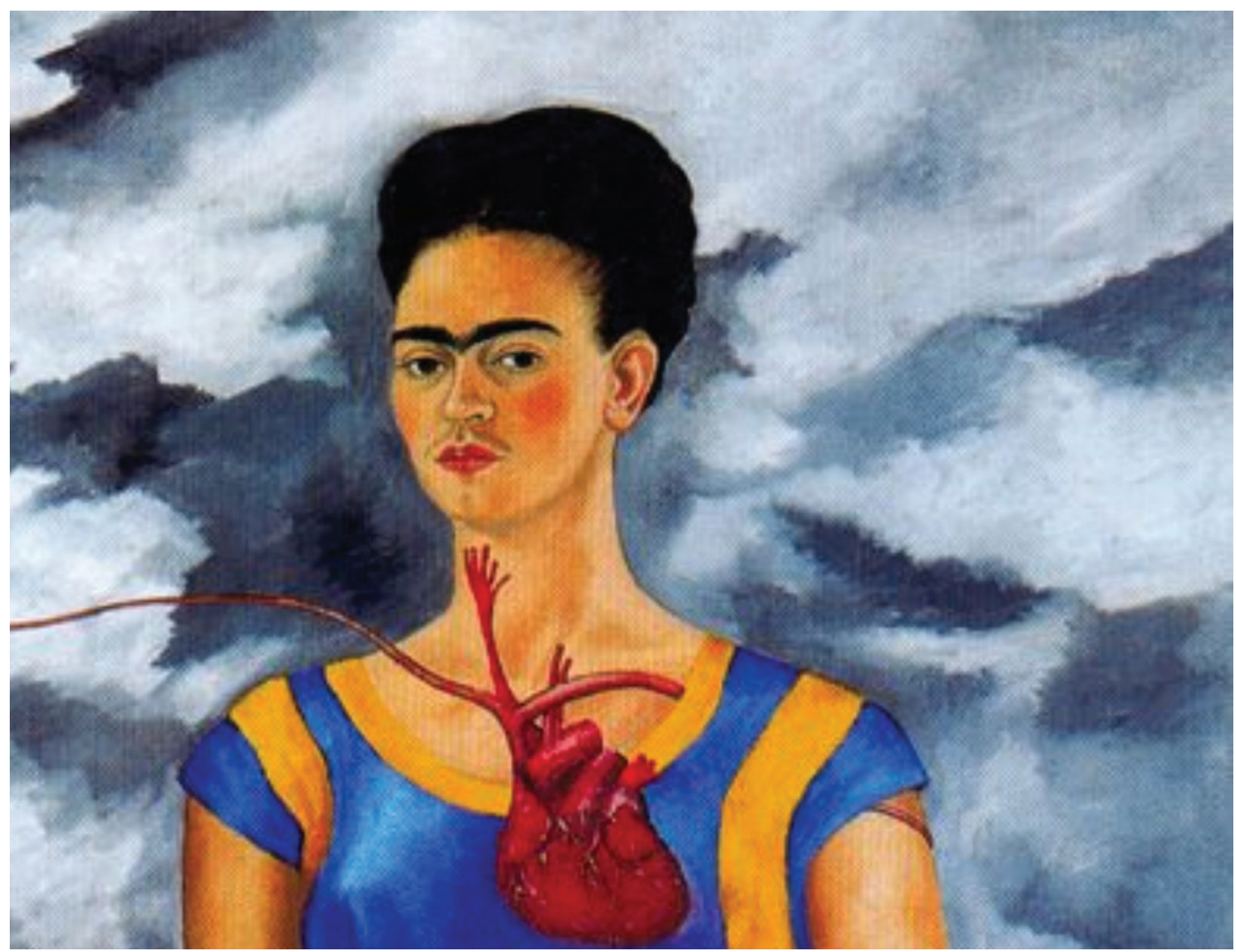

Fonte: <http:// www.googleartproject.net>. Acesso em: 24 out. de 2016.

Outro elemento de convergência que apontamos entre a estética das obras de Frida Kahlo e a coleção Viva la Vida (2015) é o padrão de flores, estampado em uma das linhas da coleção (Figura 12). ${ }^{6}$ As flores, utilizadas pela Arezzo nas sandálias, integram a identidade de Frida que fazia uso frequente delas em sua cabeça e em suas vestimentas, sempre coloridas, bordadas e adornadas com estampas vivas e floridas, como pode ser analisado nas Figuras 13 e 14.

6 O que difere essa linha da coleção das outras, de cores lisas, além da presença de estampas são os modelos dos calçados. Nesta, há espadrilles com salto e sem salto, bem como, um tipo de sapatilha de bico fino. 
Figura 12 - Padrão de estampa floral nos artefatos da coleção Viva la Vida (2015).
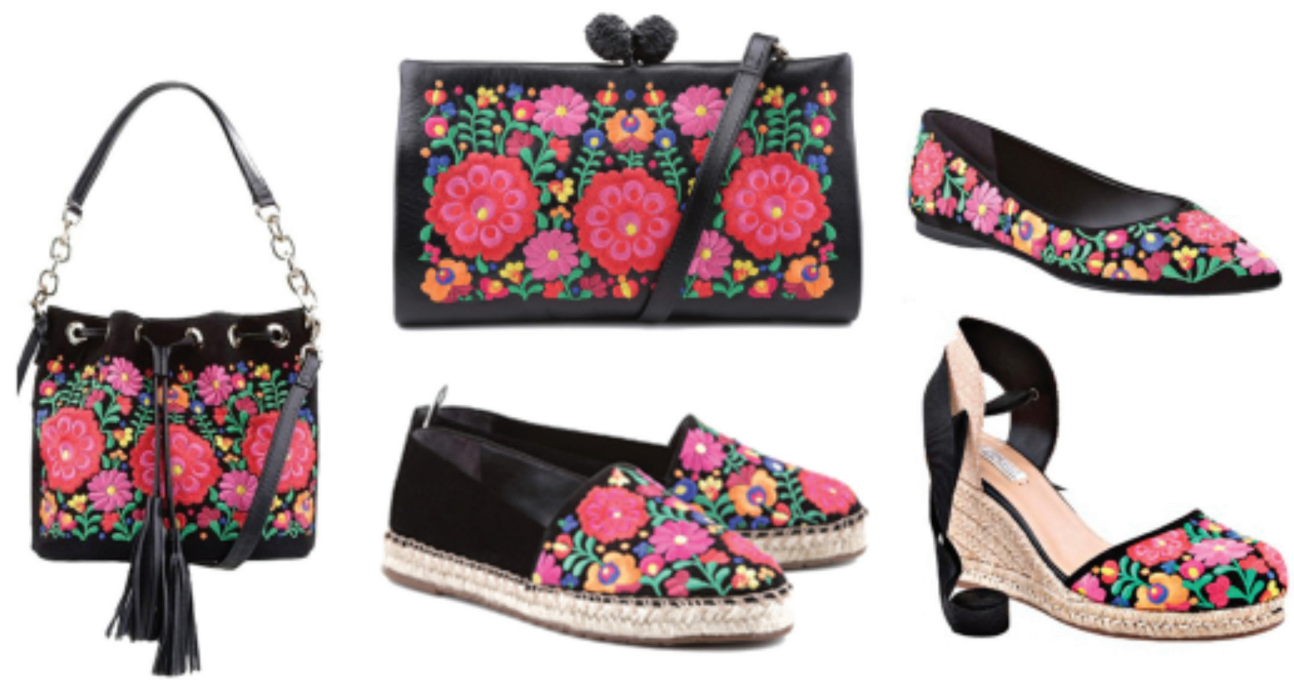

Fonte: Elaboração dos autores a partir de imagens da internet, 2016.

Figura 13 - Registro fotográfico de Frida Kahlo com flores.

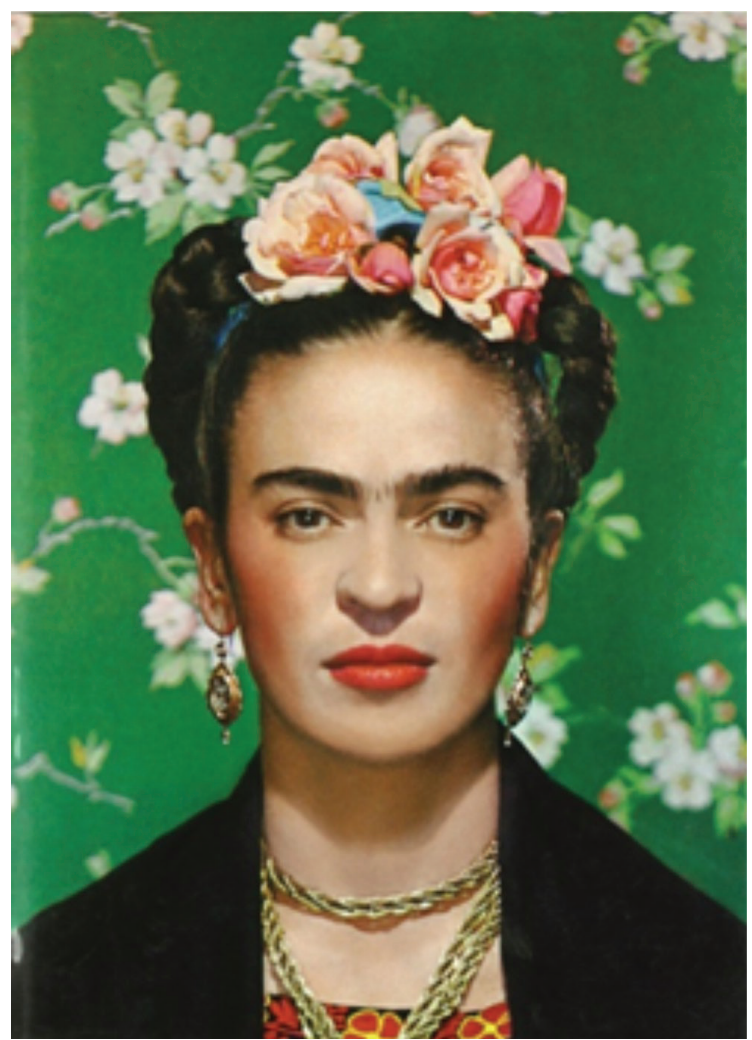

Fonte: Frida Kahlo - conexões entre mulheres surrealistas mexicanas, 2015, p. 53. 
Figura 14 - Vestimentas de Frida em exposição no Instituto Tomie Ohtake.

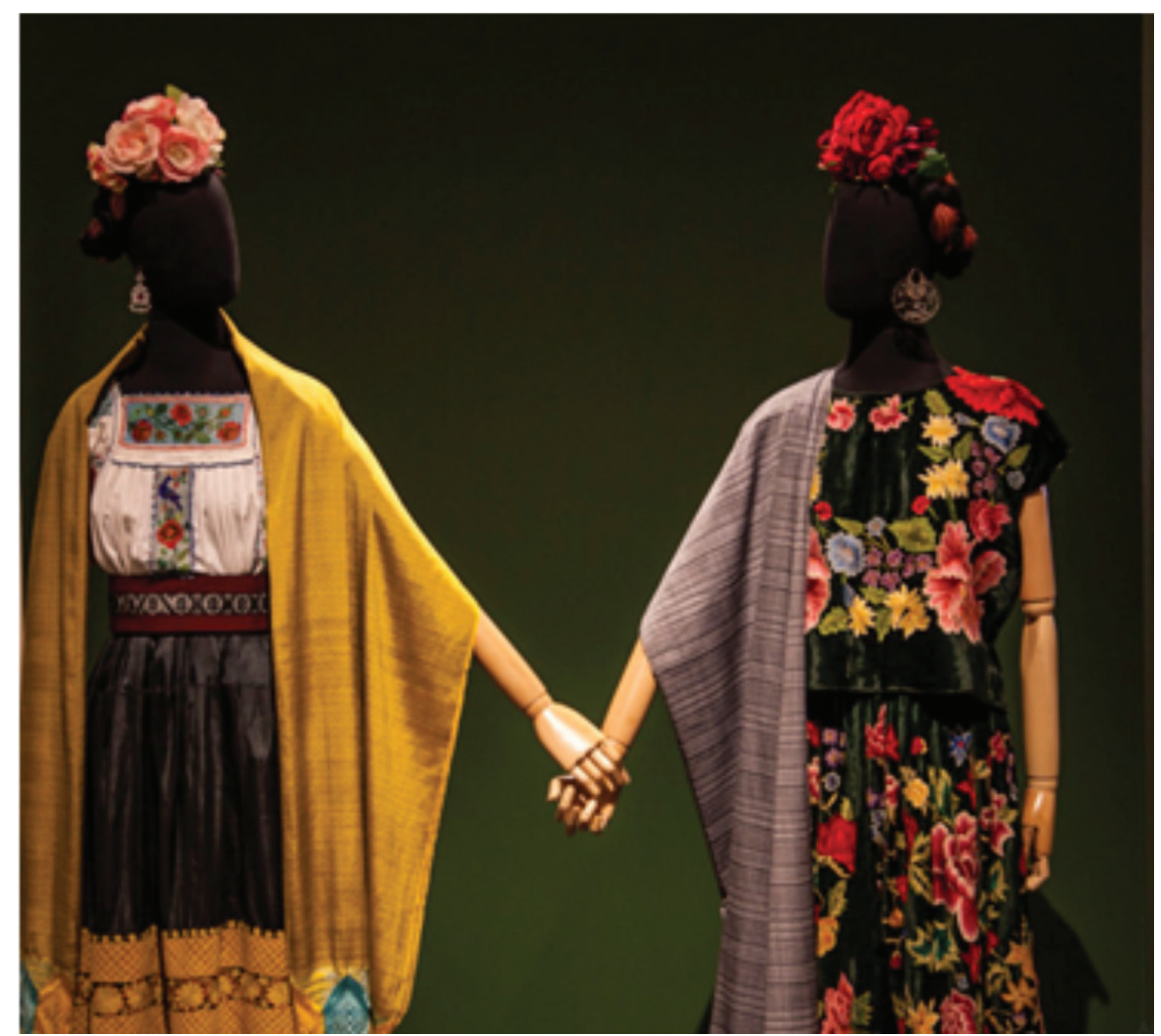

Fonte: Disponível em: <http://www.institutotomieohtake.org.br>. Acesso em: 4 nov. 2016.

Observamos que as convergências entre os elementos das obras de Frida e da cultura mexicana são apropriadas e utilizadas tanto na decoração do hall do evento de lançamento da coleção, quanto em toda a coleção de bolsas e calçados Viva la Vida (2015), que utiliza as cores vibrantes das obras de Frida, dos motivos e temas mexicanos, também pintados por ela, e dos bordados típicos da cultura da artista.

Além disso, apropriando-se da ressignificação que Frida fez a algumas cores, atribuindo a elas outros nomes, a marca Arezzo trouxe em seu catálogo algumas nomenclaturas de cores sugeridas por Frida em seu diário. Para essa análise, elencamos a linha de sandálias de salto de Viva la Vida (2015) para observar a convergência entre as cores da coleção e a pintura Viva la Vida (1954). A seguir, vemos na Figura 15 a linha de sandálias de salto alto da coleção, intitulada "sandália flor", cujos nomes das cores colocadas pela Arezzo - azul amor, pera espinhosa, sol, boa luz, sangre, ouro, pelle, prata, off-white e negro - em sua maioria, fazem menção aos nomes que Frida atribuía àquelas cores que utilizava em suas pinturas. 
Figura 15 - Sandálias Flor nas cores: pera espinhosa, azul amor, negro, pelle, sol, prata, sangre, off-white, boa luz e ouro.

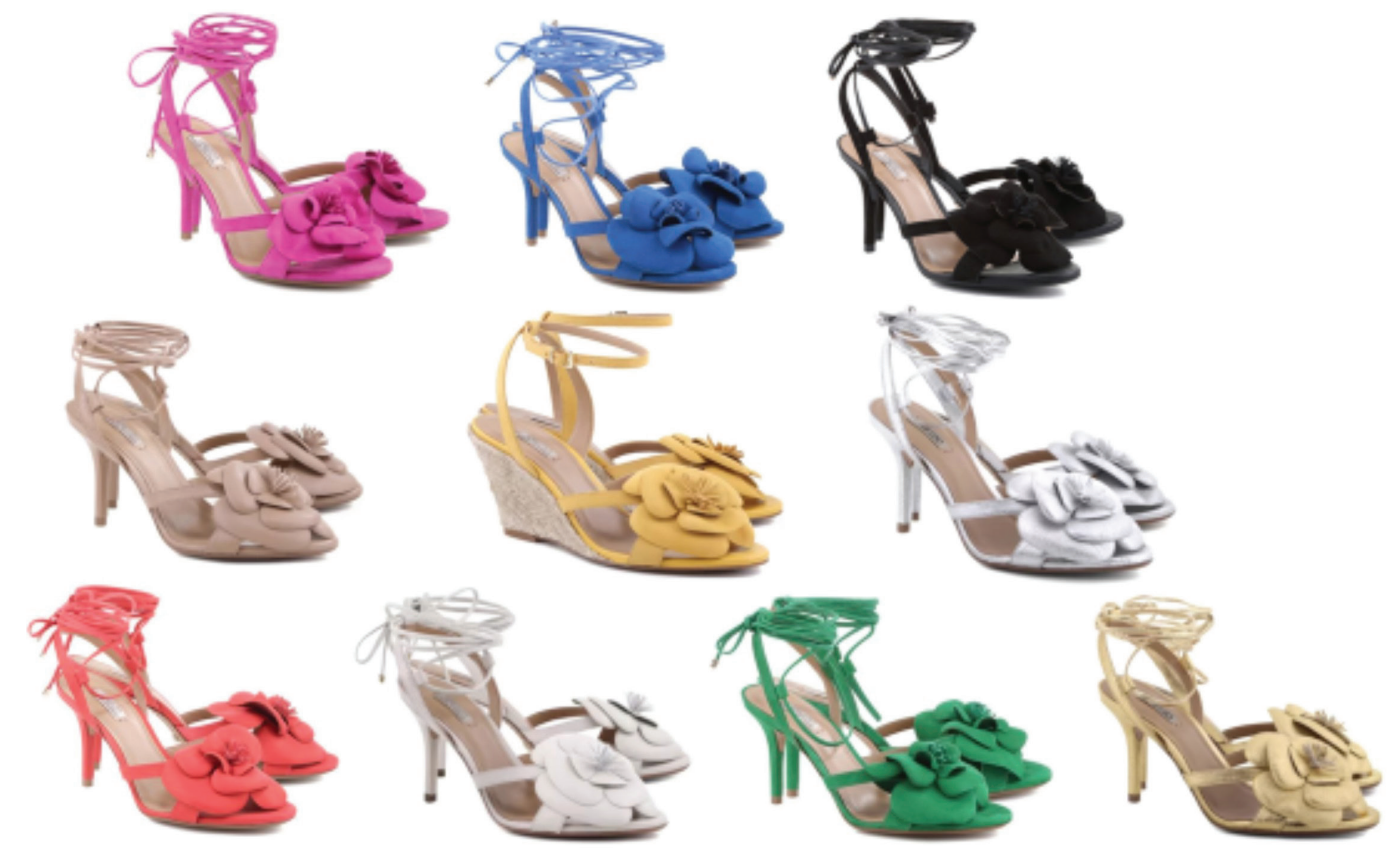

Fonte: Elaboração dos autores, 2016.

Tendo em vista os escritos da artista sobre cores, a marca utiliza tais nomes para consumir a estética do ícone de Frida, vendendo e divulgando a coleção simultaneamente à exposição de obras das artistas mexicanas. Destacamos que, além da cor amor, boa luz e sangre, as cores rosa, amarelo, marrom e preto também receberam outra nomenclatura de acordo com o diário e a língua predominante no país da artista, configurando-se, respectivamente, como pera espinhosa, sol, pelle e negro (KAHLO, 1994).

$\mathrm{Na}$ Figura 16, é possível observar os recortes da pintura Viva la Vida (1954) enfatizando as cores de sua composição e, ao lado, as flores das sandálias da coleção Viva la Vida (2015), criada pela Arezzo. Nessa montagem, fica perceptível a confluência das cores das sandálias com as cores usadas por Frida.

A partir de um degradê de tons quentes e frios, elaboramos essa paleta de modo que fosse contemplada a ordem dos elementos da pintura de Frida - céu, polpa e casca das melancias e terra - relacionando-a com as flores das sandálias da coleção da Arezzo que, por sua vez, também foram projetadas por nós numa ordem, que acompanha os tons da pintura - o que evidencia a proximidade entre Viva la Vida (1954), a pintura, e Viva la Vida (2015), a coleção de bolsas e calçados. Na coluna das flores, à esquerda, as cores estão dispostas na sequência, of-white, prata, azul amor, sangre, pera espinhosa, boa luz, sol, ouro, pelle e negro, acompanhando os tons recortados da pintura, evidenciados pelo branco, azuis, vermelho, coral, carmim, verde claro, verde escuro, e pelos tons terrosos de marrom. 
Figura 16 - Paleta de cores do Díptico Viva la Vida.

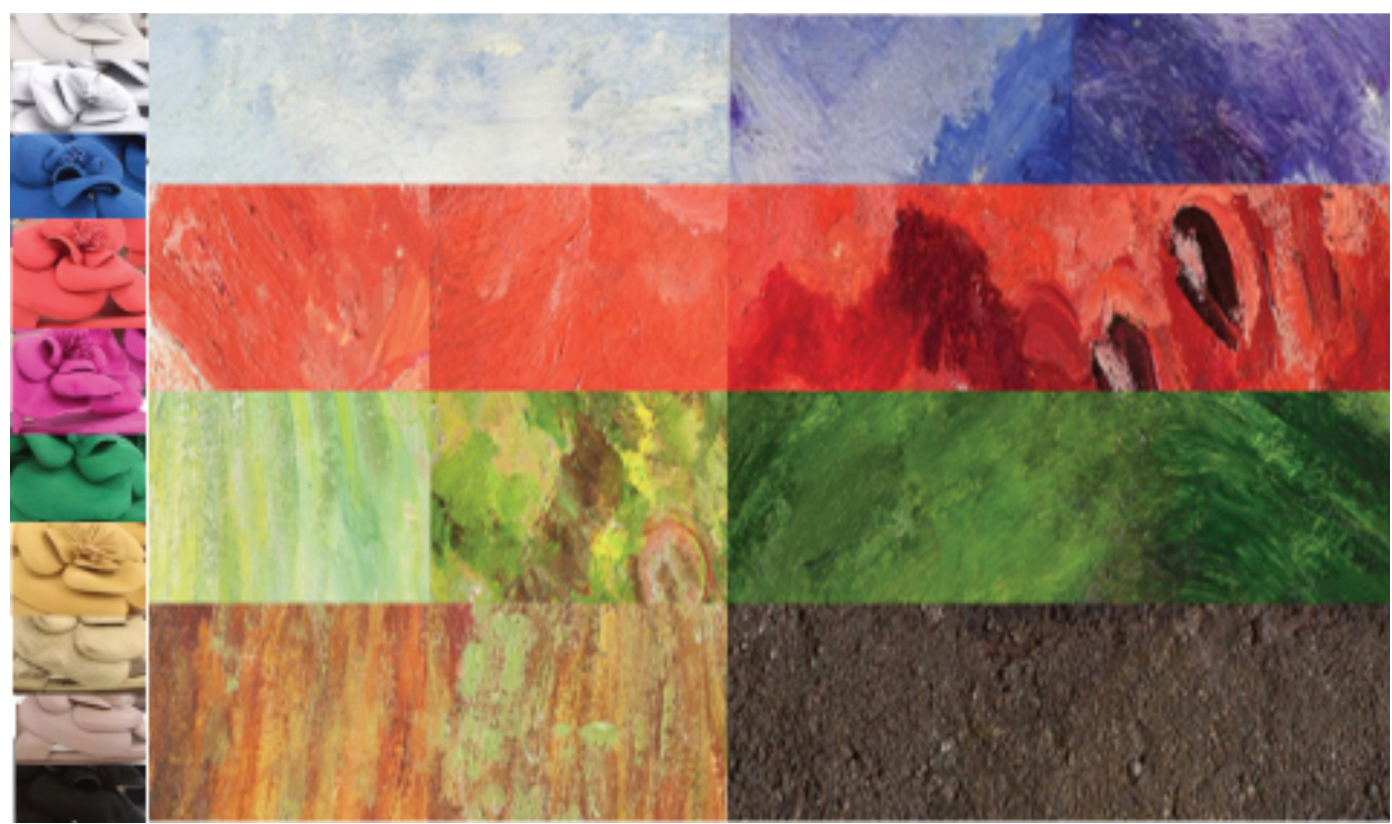

Fonte: Elaboração dos autores, 2016.

Vemos que as aproximações entre os componentes dessas duas versões de Viva la Vida são várias, por exemplo, as cores das melancias, do céu e da terra e as das sandálias. Cada cor foi associada por nós a elementos naturais e também subjetivos. O vermelho na pintura destaca-se por sua vivacidade, simbolizando "sangue", sendo citado pela artista em seu diário e associado à fertilidade simbolizada pela fruta melancia (KAHLO, 1994). O verde, em algumas cascas, está iluminado pela cor amarela, imitando assim o reflexo da luz solar. O marrom, presente não só na terra, mas em boa parte de uma casca próxima ao chão, nos remonta ao solo. Já o azul, do céu límpido, manchado de branco das nuvens, traz consigo uma atmosfera serena, propondo a liberdade e desprendendo a própria pintura dos cenários comuns de frutas sobre mesas.

\section{CONSIDERAÇÕES FINAIS}

Quando utiliza o nome, os temas, padrões e referências de Frida, em nosso entender, a Arezzo classifica a arte da artista em relação à cultura mexicana, colocando sua estética voltada puramente para a arte local, invisibilizando o íntimo de seu autorretrato e os significados atribuídos pela artista, por exemplo, em relação às suas cores. Analisamos assim, pois, em um dos discursos veiculados no site oficial da marca, a Arezzo se pronuncia sobre uma das sandálias flor, de cor azul amor, inferindo que tal calçado "tem tudo a ver com a estética e arte mexicana", acrescentando ainda que a "flor grande é o destaque do sapato, que ainda ganha o detalhe de amarrações no tornozelo e conforto do salto médio. Para divar!" (AREZZO, 2015). 
Pensar a coleção Viva la Vida (2015), de modo genérico, reduz a simbologia do próprio nome da coleção, inspirado explicitamente na obra, e na vida de Frida Kahlo. Com isso, apontamos que apesar de a marca fazer menção a Frida por meio do título da coleção, do padrão das flores das sandálias e da nomenclatura das cores composta pelos significados que Frida atribuía a elas, analisamos que existe também uma exaltação da região em que as artistas da exposição residiam. Essa exaltação se dá tanto através da "vitrine-ilha" no hall de lançamento, como do cenário que compunha as fotos da campanha publicitária, e também do discurso localizado no site oficial da marca em que, na descrição de uma das sandálias, de cor "azul amor", é enaltecida a combinação com a estética e arte mexicana.

Ao analisarmos as duas versões Viva la Vida, encontramos regularidades referentes às cores, aos títulos, e aos elementos que reforçam a identidade de Frida Kahlo, e de sua imagem como ícone da cultura popular passível de ser consumido em diferentes meios. Com isso, inferimos que o artístico, enquanto produção cultural, conhecimento técnico, e expressão da sensibilidade humana, pode permear e envolver nossa visão antes mesmo de conhecermos, a fundo, que determinado artefato é dotado de referências e alusões a alguma obra de arte, artista e movimento histórico. Assim, este estudo sobre as relações entre as imagens contemporâneas e o repertório artístico nos mostra que as visualidades se reinventam diante das constantes mudanças da sociedade e que, sob tais condições parece, no mínimo, impertinente insistir na segregação entre erudito e popular como se fossem binários opostos passíveis de tal classificação. Constatamos que a convergência entre os elementos dos calçados analisados e da pintura Viva la Vida (1954) reflete o modo como o artístico institucional pode vir a ser discutido, analisado e estudado tendo por base produtos comerciais consumidos pelos sujeitos contemporâneos.

Assim, em nosso entendimento, as ações daqueles/as responsáveis/as pela produção, circulação e sistematização do conhecimento, como professores/as e pesquisadores/as precisam visibilizar o imbricamento entre as referências artísticas e as visualidades que permeiam a cultura popular, como aquelas encontradas nas imagens da Arezzo.

Por fim, destacando a produção artística e cultural de Frida Kahlo como possibilidade de (res)significações de sentidos na contemporaneidade, uma vez que, mesmo que o repertório da artista esteja relacionado com os elementos à sua volta, como acontece com outros/as artistas, também compõe implícita e explicitamente as vitrines, as ruas, os teatros e os shoppings, provocando concepções artísticas diferentes daquelas que comumente permeiam os materiais de caráter intencionalmente educacional.

Por isso, consideramos que não só a produção e a figura de Frida, mas a produção de outros/as artistas e períodos da História da Arte podem estar dispersas em vários elementos da nossa cultura, podendo ser analisados e lidos, especialmente nas propostas educativas, numa perspectiva que provoque e suscite múltiplas interpretações e leituras, favorecendo assim, a reflexão sobre a produção de subjetividades e identidades dos e pelos sujeitos. 


\section{REFERÊNCIAS}

ALVES, Júlia B. Um brinde à identidade, à diversidade e à alteridade: um passeio pelo mundo dos mortos no sul do México. Abehache: Revista da Associação Brasileira de Hispanistas. São Paulo: v. 8, n. 1, p. 53-72, jan./jun. 2015.

ARAS, Lina M. B. Um olhar sobre a arte de Frida Kahlo. In: IV ENCONTRO DA ASSOCIAÇÃO NACIONAL DE PESQUISADORES E PROFESSORES DE HISTÓRIA DAS AMÉRICAS. Anais eletrônicos... Salvador: USP, 2000, p. 1- 15. Disponível em: <http:// anphlac.fflch.usp.br> Acesso em: 13 out. 2016.

ARCQ, Teresa (curadora). Introdução. In: FRIDA KAHLO: conexão entre mulheres surrealistas no México: exposição: de 27 setembro de 2015 a 10 de janeiro de 2016, Instituto Tomie Ohtake. São Paulo, SP: Ed. Bilíngue: português/inglês. Realização Ministério da Cultura: Lei Federal de Incentivo à Cultura.

AREZZO. Disponível em: <https://www.arezzo.com.br>. Acesso em: set./nov. 2016.

FRIDA KAHLO: conexão entre mulheres surrealistas no México: exposição: de 27 setembro de 2015 a 10 de janeiro de 2016, Instituto Tomie Ohtake. São Paulo, SP: Ed. Bilíngue: português/inglês. Realização Ministério da Cultura: Lei Federal de Incentivo à Cultura.

HAGHENBECK, Francisco Geraldo. O segredo de Frida Kahlo. Tradução de Luis Reyes Gil. São Paulo: Editora Planeta do Brasil, 2011.

HERNÁNDEZ, Fernando. Catadores da cultura visual: transformando fragmentos em nova narrativa educacional. Porto Alegre: Mediação, 2007.

KAHLO, Frida. O diário de Frida Kahlo: um autorretrato íntimo. Rio de Janeiro: José Olympio, 1994.

KETTENMANN, Andréa. Diego Rivera: um espírito revolucionário na Arte Moderna. Cidade do México: Taschen, 2001.

LAMPERT, Jociele. Arte contemporânea, cultura visual e formação docente, 2009, 159s. Tese (Doutorado Escola de Comunicação e Artes - ECA). Programa de Pós-Graduação em Artes Visuais, Universidade de São Paulo. São Paulo, SP.

LEMOS, Maria Teresa T. B. Práticas religiosas e representações simbólicas - festas e ritualidades: o dia dos mortos no México. In: ANPUH - XXV SIMPÓSIO NACIONAL DE HISTÓRIA. Anais eletrônicos... Fortaleza: 2009. Disponível em: <http://anais.anpuh. org/> Acesso em: 13 out. 2016.

LEVINZON, Gina Khafif. Frida Kahlo: a pintura como processo de busca de si mesmo. Revista Brasileira de Psicanálise. São Paulo: v. 1, n. 2, p. 49-60, jun. 2009.

MUSEO FRIDA KAHLO. Frida Kahlo Museu. Disponível em: $<$ http:/www.museofridakahlo.org. $>$. Acesso em: set./nov. 2016. 
PARANÁ. Secretaria de Estado da Educação. Diretrizes Curriculares da Educação Básica - Arte. Curitiba: SEED, 2008.

PRADO, Adonia Antunes. O zapatismo na revolução mexicana: uma leitura da revolução agrária do sul. Revista Estudos, Sociedade e Agricultura, v. 20, p. 144-174, abr. 2003.

SARDELICH, Maria Emília. Leitura de imagens, cultura visual e prática educativa. Cadernos de Pesquisa, v. 36, n. 128, p. 451-472, mai./ago. 2006.

SOUZA, Ana Maria Alves. Frida Kahlo: imagens (auto)biográficas, 2011, 145s. Dissertação (Mestrado Centro de Comunicação e Expressão). Programa de Pós-Graduação em Literatura, Universidade Federal de Santa Catarina. Florianópolis, SC.

VASCONCELLOS, Camillo de Mello. As representações das lutas de independência no México na ótica do muralismo: Diego Rivera e O’ Gorman. Revista de História, v. 1, p. 283-304, out. 2005.

\section{Dados dos Autores}

\section{Maria Eduarda Carrenho Fabrin}

Graduada em Artes Visuais pela Universidade Estadual de Maringá. Arte-educadora. Navegantes/SC - Brasil. dudacarrenhofabrin@gmail.com

\section{João Paulo Baliscei}

Doutorando em Educação na Universidade Estadual de Maringá. Professor na Universidade Estadual de Maringá. Maringá/PR - Brasil. vjbaliste@gmail.com

Bolsista da Capes/ Programa Doutorado Sanduíche no Exterior/ Processo $\mathrm{n}^{\circ}$ $\{88881.131578 / 2016-01\}$

\section{Vinícius STein}

Doutorando em Educação na Universidade Estadual de Maringá. Professor na Universidade Estadual de Maringá. Maringá/PR - Brasil. vsteiin@gmail.com

Submetido em: 10-02-2017

Aceito em: 26-04-2017 